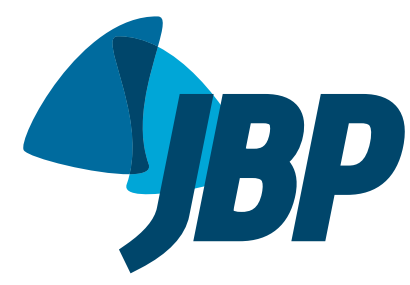

1. Programa de Pós-Graduação em Ciências da Saúde, Universidade Federal da Bahia - UFBA Salvador (BA) Brasil.

2. Núcleo de Excelência em Asma/ Programa para o Controle da Asma na Bahia - ProAR - Salvador (BA) Brasil.

3. Programa de Pós-Graduação em Medicina e Saúde, Universidade Federal da Bahia - UFBA - Salvador (BA) Brasil.

4. Faculdade de Medicina de Ribeirão Preto, Universidade de São Paulo, Ribeirão Preto (SP) Brasil.

5. Instituto de Ciências da Saúde Universidade Federal da Bahia - UFBA Salvador (BA) Brasil.

6. Faculdade de Medicina de Jundiaí, Jundiaí (SP) Brasil.

7. Faculdade de Medicina da Bahia, Universidade Federal da Bahia - UFBA Salvador (BA) Brasil.

a. (D) http://orcid.org/0000-0002-7627-7298

b. (D) http://orcid.org/0000-0001-5043-0613

c. (D) http://orcid.org/0000-0001-8919-1672

d. (D) http://orcid.org/0000-0001-8479-3666

e. (iD http://orcid.org/0000-0002-4462-8364

f. (iD) http://orcid.org/0000-0002-1475-2663

g. (iD http://orcid.org/0000-0003-4868-0124

h. (D) http://orcid.org/0000-0002-7403-3871

Submitted: 29 January 2017

Accepted: 22 December 2017.

Study carried out at the Núcleo de

Excelência em Asma/Programa para o

Controle da Asma na Bahia - ProAR -

Salvador (BA) Brasil.

\section{Obesity and asthma: clinical and laboratory characterization of a common combination}

Juliana Pires Viana de Jesus ${ }^{1,2, a}$, Aline Silva Lima-Matos ${ }^{2,3, b}$, Paula Cristina Andrade Almeida ${ }^{2, c}$, Valmar Bião Lima ${ }^{2, d}$, Luane Marques de Mello,e, Adelmir Souza-Machado 2,5,f, Eduardo Vieira Ponte ${ }^{5,6, \mathrm{~g}}$, Álvaro Augusto Cruz $\mathrm{Z}^{2,7, \mathrm{~h}}$

\begin{abstract}
Objective: To evaluate the relationship between obesity and asthma. Methods: This was a preliminary cross-sectional analysis involving 925 subjects with mild-to-moderate or severe asthma evaluated between 2013 and 2015. Obesity was defined on the basis of body mass index (BMI) and abdominal circumference. We collected clinical, laboratory, and anthropometric parameters, as well as pulmonary function test results and data regarding comorbidities. The subjects also completed asthma control and quality of life questionnaires. Results: Obese individuals had a significantly higher number of neutrophils in peripheral blood than did nonobese individuals $(p=0.01)$. Among the obese individuals, 163 (61\%) had positive skin-prick test results, as did $69 \%$ and $71 \%$ of the individuals classified as being overweight or normal weight, respectively. Obese individuals showed lower spirometric values than did nonobese individuals, and $32 \%$ of the obese individuals had uncontrolled asthma, a significantly higher proportion than that found in the other groups $(p=0.02)$. Conclusions: Obese individuals with asthma seem to present with poorer asthma control and lower pulmonary function values than do nonobese individuals. The proportion of subjects with nonatopic asthma was higher in the obese group. Our results suggest that obese individuals with asthma show a distinct inflammatory pattern and are more likely to present with difficult-to-control asthma than are nonobese individuals.
\end{abstract}

Keywords: Asthma; Obesity; Overweight; Eosinophilia.

\section{INTRODUCTION}

Asthma and obesity are very prevalent diseases and are considered public health problems. Evidence from cross-sectional studies suggests that obese individuals are at increased risk of asthma and that obese individuals with asthma have more severe asthma, experience a greater number of hospitalizations, and make a greater number of emergency room visits. ${ }^{(1,2)}$ However, the causal association of obesity with asthma prevalence and severity remains an object of study.

Studies aimed at clarifying the relationship between obesity and asthma have suggested that obesity has effects on respiratory mechanics, alters immune response, and has metabolic implications. ${ }^{(1,3-5)}$ There is evidence that obesity increases the inflammatory process in the lungs of subjects with asthma. Pro-inflammatory mediators are directly correlated with abdominal visceral fat and can lead to increased bronchial hyperresponsiveness and bronchospasm. ${ }^{(6,7)}$ Cross-sectional studies have also suggested that obese individuals with asthma have airway inflammation that is more neutrophilic than eosinophilic. ${ }^{(7,8)}$

Studies evaluating the relationship between obesity and asthma control have reported controversial findings. ${ }^{(9,10)}$ In addition, there have been few studies evaluating the effects of obesity on the immunopathology of asthma. Therefore, the objective of the present study was to

Correspondence to:

Juliana Pires Viana de Jesus. NEA/ProAR - UFBA. Rua Carlos Gomes, Edifício Multicentro de Saúde Carlos Gomes, $7^{\circ}$ andar, CEP 40060-330, Salvador, BA, Brasil.

Tel./Fax: 5571 3013-8462. E-mail: juliana.neasma@gmail.com

Financial support: This study received financial support from the Brazilian Conselho Nacional de Desenvolvimento Cientifico e Tecnológico ICNPq, National Counsel for Scientific and Technological Development; PRONEX Mandate no. 020/2009) and the Fundação de Amparo à Pesquisa do Estado da Bahia (FAPESB, Foundation for the Support of Research in the State of Bahia; Grant no. 6353 PNX 0018/2009). 
evaluate the relationship between obesity and asthma, regarding peripheral eosinophilia and neutrophilia, atopy, asthma severity, asthma control, and late-onset asthma.

\section{METHODS}

\section{Study design}

This was a cross-sectional study evaluating subjects with mild-to-moderate or severe asthma. A total of 925 subjects treated by the Brazilian Unified Health Care System in the city of Salvador, Brazil, participated in the study. Participants were selected between January 2013 and July 2015 and were evaluated at the Federal University of Bahia Center of Excellence in Asthma, located in that same city. This study is part of a more comprehensive project, called "Fatores de risco, biomarcadores e endofenótipos da asma grave" (Risk factors and biomarkers for and endophenotypes of severe asthma) that was approved by the Brazilian National Research Ethics Committee (Ruling/Resolution no. 450/2010) and the Research Ethics Committee of the Federal University of Bahia Climério de Oliveira Maternity Hospital (Additional Resolution no. 095/2012).

\section{Study population}

Posters were placed in areas heavily used by pedestrians and in public transport vehicles, in order to recruit subjects with mild-to-moderate asthma throughout the city of Salvador. In addition, the research team advertised the study among patients and physicians at the primary care clinics affiliated with the public health care system in the city of Salvador, and interviews were conducted in the waiting rooms of those clinics. Subjects with severe asthma were selected from the cohort of subjects enrolled in the Programa para o Controle da Asma na Bahia (ProAR, Bahia State Program for the Control of Asthma), which is a major referral program providing specialized care in the treatment of severe asthma in the city of Salvador. ${ }^{(11)}$

The inclusion criteria were having physician-diagnosed asthma and being $\geq 18$ years of age. All participants gave written informed consent. The exclusion criteria were being pregnant, having any disease severe enough to make it difficult to assess asthma symptoms or any other disease that causes dyspnea.

The subjects with mild-to-moderate asthma recruited from the community and primary care clinics were referred to a specialist at the Núcleo de Excelência em Asma-ProAR (NEA, Center of Excellence in Asthma-ProAR) at the Federal University of Bahia for confirmation of the diagnosis of asthma. For the subjects with severe asthma recruited from the cohort of subjects enrolled in the ProAR, the diagnosis of asthma was validated by two specialists at the NEA-ProAR. The specialists evaluated the subjects and reviewed their medical charts in order to confirm the diagnosis of asthma. The criteria for diagnosing asthma were typical symptoms, symptomatic improvement with a bronchodilator or an inhaled corticosteroid, and a 12\% and $200 \mathrm{~mL}$ increase in $\mathrm{FEV}_{1}$ after bronchodilator use.

The subjects were classified as having mild-tomoderate asthma in accordance with the 2006 Global Initiative for Asthma guidelines ${ }^{(12)}$ in order to use similar criteria to those used among the subjects with severe asthma, whose asthma severity was evaluated in accordance with the 2002 Global Initiative for Asthma guidelines, ${ }^{(13)}$ which were in effect at the time the ProAR was established, and who fit the category of having untreated severe asthma as per the classification proposed to the World Health Organization in 2010. ${ }^{(14)}$

\section{Study procedures}

All subjects underwent blood collection, spirometry, ${ }^{(15,16)}$ immediate skin-prick testing, ${ }^{(17)}$ clinical evaluation by a specialist, and collection of fasting anthropometric measurements.

All subjects also completed the following questionnaires: the six-item Asthma Control Questionnaire(18); the Asthma Quality of Life Questionnaire ${ }^{(19)}$; the Symptom Questionnaire for Gastroesophageal Reflux Disease ${ }^{(20)}$; and the Beck Depression Inventory. ${ }^{(21)}$

\section{Definitions}

Subjects with difficult-to-control asthma are those whose lack of asthma control is due to factors such as low adherence to medication, poor inhaler technique, environmental exposure, psychosocial problems, or comorbidities. $^{(14)}$

Uncontrolled asthma was defined as a score $\geq 1.5$ on the six-item Asthma Control Questionnaire. ${ }^{(18)}$

A high dose of inhaled corticosteroid was defined as use of more than $800 \mu \mathrm{g}$ of budesonide daily. ${ }^{(22)}$

The criteria for the presence of airway obstruction were an $\mathrm{FEV}_{1}<80 \%$ of predicted and an $\mathrm{FEV}_{1} / \mathrm{FVC}$ ratio below the lower limit of normal.(23) This limit is adjusted for age, being obtained on the basis of the fifth percentile of healthy nonsmokers.

The criterion for the presence of atopy was a positive, immediate skin-prick test result. A test result was considered positive if the wheal to any allergen tested was $\geq 3 \mathrm{~mm}$. The antigens tested were Dermatophagoides pteronyssinus, Aspergillus flavus, Dermatophagoides farinae, Aspergillus fumigatus, Blomia tropicalis, Aspergillus niger, cat dander, Alternaria alternata, dog dander, Blatella germanica, Cladosporium herbarum, Periplaneta americana, Paspalum notatum, and Cynodon dactylon. ${ }^{(17)}$

Late-onset asthma was defined as asthma diagnosed at age 18 years or older. ${ }^{(24)}$ Eosinophilic asthma was defined as a peripheral blood eosinophil count greater than 260 cells/ $\mu \mathrm{L}$. Zhang et al.,(25) demonstrated that this cut-off point of peripheral blood eosinophil count has good ability to detect induced sputum eosinophilia.

The diagnostic criterion for comorbidities (hypertension, dyslipidemia, and/or diabetes) was a positive report of use of specific medications for each of those diseases. 
Body weight was measured with a digital scale (Tanita, Arlington Heights, IL, USA), and height was measured with a wall-mounted wooden stadiometer graduated in $\mathrm{cm}$ from 40 to 220 . Body mass index was calculated as body weight in kilograms divided by height in meters squared. ${ }^{(26)}$ Obesity was defined on the basis of BMI (kg/ $\mathrm{m}^{2}$ ) in accordance with the World Health Organization criteria-underweight: BMI < 18.5; normal weight: $18.5 \leq$ BMI $\leq 24.9$; overweight: $25 \leq \mathrm{BMI} \leq 29.9$; and obesity: BMI $\geq 30$.(26) Abdominal obesity was classified using abdominal circumference (AC), which was measured at the midpoint between the lowest rib and the iliac crest. Abdominal obesity was defined as an $A C \geq 80 \mathrm{~cm}$ in women and $\geq 90 \mathrm{~cm}$ in men. ${ }^{(27)}$

\section{Statistical analysis}

We used the Statistical Package for the Social Sciences for Windows, version 17.0 (SPSS Inc., Chicago, IL, USA). Associations were analyzed by BMI group and by abdominal obesity group. The chi-square test was used to detect associations between dichotomous variables, and the nonparametric Kruskal-Wallis test was used to compare three or more independent groups on continuous or ordinal variables. The Mann-Whitney test was used to compare two groups on continuous and ordinal variables with non-normal distribution. Continuous and ordinal variables are presented as mean and standard deviation and as median and interquartile range, respectively. Categorical variables are presented as absolute numbers and percentages.

\section{RESULTS}

We included 925 subjects with asthma, and, of those, 299 were obese according to their BMI. Table 1 presents the characteristics of participants by BMI group. As can be seen in this table, BMI was associated with gender, age, level of education, comorbidities, atopy, dose of inhaled corticosteroid, eosinophilic phenotype, and peripheral blood neutrophils $(p<0.05)$.

Table 2 also presents data on participants by BMI group. Although BMI was associated with various pulmonary function parameters $(p<0.05)$, there was no significant difference in the frequency of airway obstruction among the groups. BMI was associated with asthma symptoms, asthma-related quality of life, asthma exacerbations, and difficult-to-treat asthma ( $p<0.05)$.

Tables 3 and 4 present data on participants by abdominal obesity group. The groups differed in gender, age, level of education, late-onset asthma, comorbidities, atopy, dose of inhaled corticosteroid, eosinophilic phenotype, pulmonary function, asthma symptoms, asthma-related quality of life, and frequency of exacerbations $(p<0.05)$.

\section{DISCUSSION}

Our findings indicated that obese subjects with asthma had a higher number of neutrophils and a lower number of eosinophils in peripheral blood compared with nonobese subjects with asthma. These observations suggest that asthma in obese individuals more commonly has a noneosinophilic immunopathological mechanism. This helps understand why obese subjects have more severe asthma, given that eosinophilic airway inflammation has better response to inhaled corticosteroid therapy. $(7,8,10,28)$

In our study, we analyzed immediate skin-prick test results because a positive result on this test is a

Table 1. Sociodemographic, clinical, and laboratory characteristics of the subjects included in the study, by body mass index group. ${ }^{a}$

\begin{tabular}{|c|c|c|c|c|c|}
\hline \multirow[t]{2}{*}{ Variable } & \multicolumn{4}{|c|}{ BMI group } & \multirow[t]{2}{*}{ p* } \\
\hline & $\begin{array}{l}\text { Underweight } \\
\qquad(\mathrm{n}=20)\end{array}$ & $\begin{array}{l}\text { Normal weight } \\
\quad(n=286)\end{array}$ & $\begin{array}{l}\text { Overweight } \\
\text { (n = 319) }\end{array}$ & $\begin{array}{c}\text { Obese } \\
(n=299)\end{array}$ & \\
\hline Female gender & $17(85)$ & $203(71)$ & $245(77)$ & $266(89)$ & $<0.01$ \\
\hline Age, years & $34 \pm 19$ & $40 \pm 16$ & $47 \pm 14$ & $47 \pm 13$ & $<0.01$ \\
\hline Low level of education ${ }^{\mathrm{b}}$ & $3(15)$ & $26(9)$ & $47(15)$ & $54(18)$ & 0.02 \\
\hline Late-onset asthma ( $\geq 18$ years) & $4(20)$ & $90(31)$ & $120(38)$ & $92(31)$ & 0.14 \\
\hline Comorbidities $^{c}$ & $2(10)$ & $61(21)$ & $130(41)$ & $171(57)$ & $<0.01$ \\
\hline Diagnosis of rhinitis & $18(90)$ & $258(91)$ & $300(94)$ & $277(93)$ & 0.42 \\
\hline Positive skin-prick test result & $10(50)$ & $191(67)$ & $199(62)$ & $163(55)$ & 0.03 \\
\hline Diagnosis of GERD & $8(40)$ & $101(35)$ & $141(44)$ & $149(66)$ & 0.38 \\
\hline Severe depression ${ }^{\mathrm{d}}$ & $0(0)$ & $10(4)$ & $21(7)$ & $26(9)$ & $<0.01$ \\
\hline High dose of asthma medication & $4(20)$ & $102(36)$ & $158(50)$ & $173(58)$ & $<0.01$ \\
\hline Total serum IgE, IU/mL & $237(39-642)$ & $291(115-542)$ & $261(100-451)$ & $269(105-530)$ & 0.64 \\
\hline Eosinophils $\geq 260$ cells $/ \mu \mathrm{L}$ & $15(75)$ & $141(49)$ & $141(44)$ & $134(45)$ & 0.02 \\
\hline Eosinophils, cells $/ \mu \mathrm{L}$ & $433(251-579)$ & $258(137-401)$ & $232(130-378)$ & $240(139-383)$ & 0.01 \\
\hline Neutrophils, cells/ $\mu \mathrm{L}$ & $\begin{array}{c}2,641 \\
(1,922-4,938)\end{array}$ & $\begin{array}{c}3,399 \\
(2,470-4,338)\end{array}$ & $\begin{array}{c}3,431 \\
(2,394-4,533)\end{array}$ & $\begin{array}{c}3,711 \\
(2,765-4,942)\end{array}$ & 0.01 \\
\hline
\end{tabular}

BMI: body mass index; and GERD: gastroesophageal reflux disease. aValues expressed as $\mathrm{n}(\%)$, as mean \pm $\mathrm{SD}$, or as median (interquartile range). bLow level of education: being illiterate or having had fewer than 5 years of schooling. 'Comorbidities: hypertension, diabetes, and/or dyslipidemia. dSevere depression: severe level of depression as assessed by the Beck Depression Inventory. eHigh dose of medication: based on use of inhaled corticosteroids. ${ }^{*}$ Chi-square test for categorical variables and Kruskal-Wallis test for continuous variables. 
Table 2. Spirometric values and asthma severity parameters in the subjects included in the study, by body mass index group. $^{\mathrm{a}}$

\begin{tabular}{|c|c|c|c|c|c|}
\hline \multirow[t]{2}{*}{ Variable } & \multicolumn{4}{|c|}{ BMI group } & \multirow[t]{2}{*}{ p* } \\
\hline & $\begin{array}{l}\text { Underweight } \\
\qquad(\mathrm{n}=20)\end{array}$ & $\begin{array}{l}\text { Normal weight } \\
\qquad(\mathrm{n}=286)\end{array}$ & $\begin{array}{l}\text { Overweight } \\
\text { (n=319) }\end{array}$ & $\begin{array}{c}\text { Obese } \\
\text { (n = 299) }\end{array}$ & \\
\hline Post-BD FVC, $\%$ of predicted & $82(70-93)$ & $87(79-95)$ & $86(78-95)$ & $83(75-92)$ & $<0.01$ \\
\hline Post-BD FEV ${ }_{1}, \%$ of predicted & $75(62-95)$ & $82(70-92)$ & $79(67-90)$ & $75(63-88)$ & $<0.01$ \\
\hline Post-BD FEF $25-75 \%, \%$ of predicted & $70(46-90)$ & $73(44-98)$ & $67(35-94)$ & $62(36-91)$ & 0.02 \\
\hline Post-BD FEV ${ }_{1} /$ FVC, $\%$ of predicted & $0.9(0.7-0.9)$ & $0.8(0.7-0.9)$ & $0.8(0.6-0.8)$ & $0.8(0.7-0.8)$ & $<0.01$ \\
\hline Airway obstruction ${ }^{\mathrm{b}}$ & $3(15)$ & $35(12)$ & $53(17)$ & $34(11)$ & 0.26 \\
\hline ACQ-6 score $\geq 1.5$ & $4(20)$ & $63(22)$ & $75(24)$ & $97(32)$ & 0.02 \\
\hline AQLQ score & $5.0(3.7-5.9)$ & $5(4-6)$ & $4.8(3.7-5.8)$ & $4.5(3.3-5.4)$ & $<0.01$ \\
\hline $\begin{array}{l}\text { Oral corticosteroid use for asthma } \\
\text { in the past year }\end{array}$ & $9(45)$ & $100(35)$ & $126(40)$ & $151(51)$ & $<0.01$ \\
\hline Severe difficult-to-treat asthma & $6(30)$ & $97(34)$ & $147(46)$ & $179(60)$ & 0.03 \\
\hline
\end{tabular}

BMI: body mass index; BD: bronchodilator; ACQ-6: 6-item Asthma Control Questionnaire; AQLQ: Asthma Quality of Life Questionnaire; and GERD: gastroesophageal reflux disease. aValues expressed as $\mathrm{n}(\%)$ or as median (interquartile range). ${ }^{\mathrm{b}} \mathrm{FEV}_{1}<80 \%$ and $\mathrm{FEV}_{1} / \mathrm{FVC}<$ the lower limit of normal. ${ }^{(23)} *$ Kruskal-Wallis test for continuous variables and chi-square test for categorical variables.

Table 3. Sociodemographic, clinical, and laboratory characteristics of the subjects included in the study, by abdominal obesity group. ${ }^{a}$

\begin{tabular}{|c|c|c|c|}
\hline Variable & $\begin{array}{l}\text { Without abdominal obesity } \\
\qquad(\mathrm{n}=258)\end{array}$ & $\begin{array}{l}\text { With abdominal obesity } \\
\qquad(\mathrm{n}=667)\end{array}$ & $p^{*}$ \\
\hline Female gender & $167(65)$ & $564(85)$ & $<0.01$ \\
\hline Age, years & $36 \pm 15$ & $48 \pm 14$ & $<0.01$ \\
\hline Low level of education ${ }^{\mathrm{b}}$ & $16(6)$ & $114(17)$ & $<0.01$ \\
\hline Late-onset asthma ( $\geq 18$ years) & $67(26)$ & $239(36)$ & $<0.01$ \\
\hline Comorbidities $^{c}$ & $37(14)$ & 327 (49) & $<0.01$ \\
\hline Diagnosis of rhinitis & $234(91)$ & $620(93)$ & 0.13 \\
\hline Positive skin-prick test result & $174(67)$ & $389(58)$ & 0.01 \\
\hline Diagnosis of GERD & $96(37)$ & $303(45)$ & 0.31 \\
\hline Severe depression ${ }^{d}$ & $4(2)$ & $53(8)$ & $<0.01$ \\
\hline High dose of asthma medication ${ }^{e}$ & $75(29)$ & $362(54)$ & $<0.01$ \\
\hline Total serum IgE, IU/mL & $300(114-566)$ & $262(103-498)$ & 0.20 \\
\hline Eosinophils $\geq 260$ cells $/ \mu \mathrm{L}$ & $138(54)$ & $294(45)$ & 0.01 \\
\hline Eosinophils, cells/ $\mu \mathrm{L}$ & $282(143-464)$ & $236(132-379)$ & 0.05 \\
\hline Neutrophils, cells/ $\mu \mathrm{L}$ & $3,326(2,404-4,387)$ & $3,581(2,529-4,663)$ & 0.09 \\
\hline
\end{tabular}

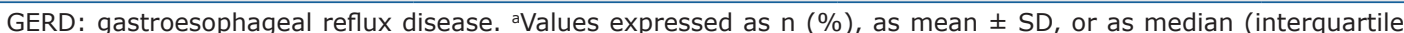
range). 'bow level of education: being illiterate or having had fewer than 5 years of schooling. 'Comorbidities: hypertension, diabetes, and/or dyslipidemia. 'Severe depression: severe level of depression as assessed by the Beck Depression Inventory. eHigh dose of medication: based on use of inhaled corticosteroids. *Chi-square test for categorical variables and Kruskal-Wallis test for continuous variables.

marker of atopy; however, obesity was associated with negative skin-prick test results. Similar findings have been observed previously, with obesity defined either by $\mathrm{BMI}$ or $\mathrm{AC}$; however, the mechanisms involving this association remain unknown. ${ }^{(29-31)}$ Interestingly, we found no association between obesity and total peripheral blood $\mathrm{IgE}$, which is also a marker of atopy. Further studies are needed to investigate whether obese individuals with asthma have lower levels of systemic Th2 immune activity or whether the association between asthma and negative skin-prick test results is due to specificities related to excess of subcutaneous adipose tissue.

Our findings also indicated an association between obesity and severe difficult-to-treat asthma. The obese individuals in our sample also had higher scores on the symptom questionnaire, poorer quality of life, and more frequent asthma exacerbations requiring oral corticosteroids than did the nonobese individuals. Although other authors have also observed these associations, ${ }^{(8,32)}$ the present study contributes to the medical literature because it included a large sample of individuals with a broad spectrum of asthma severity, recruited from a referral center and the community. In addition, the subjects in the present study were followed by specialists and were provided free-of-charge treatment to control their asthma symptoms, which was not ensured in previous studies.

The obese individuals with asthma in the present study, when considering either BMI or AC, used higher doses of inhaled corticosteroids to control their asthma. This increased dependence on inhaled corticosteroids might 
Table 4. Spirometric values and asthma severity parameters in the subjects included in the study, by abdominal obesity group. $^{\text {a }}$

\begin{tabular}{|c|c|c|c|}
\hline Variable & $\begin{array}{c}\text { Without abdominal } \\
\text { obesity } \\
\text { (n }=258)\end{array}$ & $\begin{array}{c}\text { With abdominal } \\
\text { obesity } \\
\text { (n = 667) }\end{array}$ & p* \\
\hline Post-BD FVC, $\%$ of predicted & $87(80-95)$ & $85(76-93)$ & $<0.01$ \\
\hline Post-BD FEV ${ }_{1}, \%$ of predicted & $84(72-94)$ & $77(64-89)$ & $<0.01$ \\
\hline Post-BD FEF $25-75 \%, \%$ of predicted & $78(54-101)$ & $62(35-91)$ & $<0.01$ \\
\hline Post-BD FEV ${ }_{1} / \mathrm{FVC}, \%$ of predicted & $0.8(0.7-0.9)$ & $0.8(0.6-0.8)$ & $<0.01$ \\
\hline Airway obstruction ${ }^{\mathrm{b}}$ & $29(11)$ & $96(14)$ & 0.11 \\
\hline ACQ-6 score $\geq 1.5$ & $47(18)$ & $192(29)$ & $<0.01$ \\
\hline AQLQ score & $5.1(4.2-6.0)$ & $4.6(3.4-5.6)$ & $<0.01$ \\
\hline Oral corticosteroid use for asthma in the past year & $90(35)$ & $296(44)$ & $<0.01$ \\
\hline Severe difficult-to-treat asthma & $77(29)$ & $352(53)$ & 0.63 \\
\hline
\end{tabular}

BD: bronchodilator; ACQ-6: 6-item Asthma Control Questionnaire; and AQLQ: Asthma Quality of Life Questionnaire. a Values expressed as $\mathrm{n}(\%)$ or as median (interquartile range). ${ }^{\mathrm{b}} \mathrm{FEV} \mathrm{F}_{1}<80 \%$ and $\mathrm{FEV}_{1} / \mathrm{FVC}<$ lower limit of normal. ${ }^{(23)} *$ Kruskal-Wallis for continuous variables and chi-square test for categorical variables.

be related to the lower frequency of noneosinophilic asthma in our sample of obese individuals, given that individuals with noneosinophilic asthma tend to have poorer response to corticosteroid therapy and, therefore, require higher doses of medication to control inflammation. ${ }^{(10,33)}$

Previous studies have demonstrated a relationship between age at asthma onset and the severity of respiratory symptoms in obese individuals. ${ }^{(30,34)}$ We found no association between obesity and late-onset asthma in our sample. This is an important observation because it indicates that age at symptom onset did not bias the relationship between obesity and asthma severity in our study.

Data in the literature show that, in terms of pulmonary function, obese individuals have restrictive lung disease, probably because of changes in body structure. ${ }^{(35,36)}$ Although we did not measure lung volumes to confirm the presence of restrictive lung disease, decreased FVC values in obese individuals indicate a higher frequency of restrictive lung disease than that found in nonobese individuals. We also observed that, when obesity was defined on the basis of $A C$, lung volumes were lower. The literature reports that increased abdominal adiposity may reflect poorer pulmonary function. ${ }^{(31)}$ The pathophysiological mechanism of more severe asthma in obese individuals might be in part related to structural changes in the rib cage rather than exclusively to a lower airway pathology. This hypothesis is supported by the lack of association between obesity and obstructive lung disease in our sample.

Obese individuals with asthma had a higher frequency of comorbidities. Obesity is associated with an increased frequency of comorbidities in individuals without asthma; therefore, our findings were expected. ${ }^{(37,38)}$
Comorbidities might contribute to a change in asthma severity in obese individuals, which may be clarified in future studies.

One strength of the present study is that we evaluated subjects recruited from the community and from primary and secondary care clinics, which increases the external validity of the findings. Another strength is that the diagnosis of asthma was validated by a specialist. In the case of severe asthma, it is important to make the differential diagnosis with COPD and other respiratory diseases, and that diagnosis was validated by two specialists to avoid the inclusion of patients without asthma. However, as in all cross-sectional studies, it was not possible to explore the causal relationship between obesity and the study variables. A question arises as to whether neutrophilic inflammation is a different phenotype of obese individuals with asthma or is also a characteristic of obese individuals without asthma. This question still represents a gap in current knowledge and may be answered by analyzing data on individuals without asthma.

In conclusion, we found that obese subjects with asthma have poorer asthma control and poorer quality of life, require higher doses of inhaled corticosteroid, and experience a reduction in some pulmonary function parameters, such as FVC. In addition, we found a smaller proportion of subjects with eosinophilic asthma and a lower frequency of atopy among obese individuals with asthma. Therefore, our study can satisfactorily validate data on a common combination in a Brazilian population and may help improve knowledge about the influence of obesity on asthma. However, the clinical relevance of these observations should be interpreted with caution and should be examined in future studies with analyses specific to that end.

\section{REFERENCES}

1. Baffi CW, Winnica DA, Holguin F. Asthma and obesity: mechanisms and clinical implications. Asthma Res Pract. 2015:1:1. https://doi. org/10.1186/s40733-015-0001-7

2. Barros LL, Souza-Machado A, Corrêa LC, Santos JS, Cruz C, Leite

$\mathrm{M}$, et al. Obesity and poor asthma control in patients with severe asthma. J Asthma. 2011:48(2):171-6. https://doi.org/10.3109/02770 903.2011 .554940

3. Capelo AV, Fonseca VM, Peixoto VM, Carvalho SR, Guerino LG. 
Central obesity and other factors associated with uncontrolled asthma in women. Allergy Asthma Clin Immunol. 2015;11(1):12. https://doi.org/10.1186/s13223-015-0076-y

4. Dias-Júnior SA, Reis M, de Carvalho-Pinto RM, Stelmach R, Halpern A, Cukier A. Effects of weight loss on asthma control in obese patients with severe asthma. Eur Respir J. 2014;43(5):1368-77 https://doi.org/10.1183/09031936.00053413

5. Lavoie KL, Bacon SL, Labrecque M, Cartier A, Ditto B. Higher BMI is associated with worse asthma control and quality of life but not asthma severity. Respir Med. 2006;100(4):648-57. https://doi org/10.1016/j.rmed.2005.08.001

6. Arteaga-Solis E, Zee T, Emala CW, Vinson C, Wess J, Karsenty $\mathrm{G}$. Inhibition of leptin regulation of parasympathetic signaling as cause of extreme body weight-associated asthma. Cell Metab. 2013;17(1):35-48. https://doi.org/10.1016/j.cmet.2012.12.004

7. Scott HA, Gibson PG, Garg ML, Wood LG. Airway inflammation is augmented by obesity and fatty acids in asthma. Eur Respir $\mathrm{J}$ 2011;38(3):594-602. https://doi.org/10.1183/09031936.00139810

8. van Veen $I H$, Ten Brinke A, Sterk PJ, Rabe KF, Bel EH. Airway inflammation in obese and nonobese patients with difficult-to-treat asthma. Allergy. 2008;63(5):570-4. https://doi.org/10.1111/j.1398 9995.2007.01597.x

9. Clerisme-Beaty EM, Karam S, Rand C, Patino CM, Bilderback A Riekert KA, et al. Does higher body mass index contribute to worse asthma control in an urban population? J Allergy Clin Immunol. 2009;124(2):207-12. https://doi.org/10.1016/j.jaci.2009.05.034

10. Telenga ED, Tideman SW, Kerstjens HA, Hacken NH, Timens W, Postma DS, et al. Obesity in asthma: more neutrophilic inflammation as a possible explanation for a reduced treatmen response. Allergy. 2012;67(8):1060-8. https://doi.org/10.1111/j.13989995.2012.02855.x

11. Cruz AA, Souza-Machado A, Franco R, Souza-Machado C, Ponte EV Moura Santos $P$, et al. The impact of a program for control of asthma in a low-income setting. World Allergy Organ J. 2010;3(4):167-74. https://doi.org/10.1097MOX.0b013e3181dc3383

12. Global Initiative for Asthma (GINA). Global strategy for asthma management and prevention 2006; Bethesda: GINA; 2006.

13. Global Initiative for Asthma (GINA). Global strategy for asthma management and prevention. Bethesda: GINA; 2002

14. Bousquet J, Mantzouranis E, Cruz AA, Aït-Khaled N, Baena-Cagnan $\mathrm{CE}$, Bleecker ER, et al. Uniform definition of asthma severity, control, and exacerbations: document presented for the World Health Organization Consultation on Severe Asthma. J Allergy Clin Immunol. 2010;126(5):926-38. https://doi.org/10.1016/j.jaci.2010.07.019

15. Pereira CA, Sato T, Rodrigues SC. New reference values for forced spirometry in white adults in Brazil. J Bras Pneumol. 2007;33(4):397406. https://doi.org/10.1590/S1806-37132007000400008

16. Standardization of Spirometry, 1994 Update. American Thoracic Society. Am J Respir Crit Care Med. 1995;152(3):1107-36. https:// doi.org/10.1164/ajrccm.152.3.7663792

17. Bousquet J, Heinzerling L, Bachert C, Papadopoulos NG, Bousquet PJ, Burney PG, et al. Practical guide to skin prick tests in allergy to aeroallergens. Allergy. 2012;67(1):18-24. https://doi.org/10.1111/ j.1398-9995.2011.02728.x

18. Leite M, Ponte E, Petroni J, D'Oliveira Júnior A, Pizzichini E, Cruz AA Evaluation of the asthma control questionnaire validated for use in Brazil. J Bras Pneumol. 2008;34(10):756-63. https://doi.org/10.1590/ S1806-37132008001000002

19. Juniper EF, Buist AS, Cox FM, Ferrie PJ, King DR. Validation of a standardized version of the Asthma Quality of Life Questionnaire. Chest, 1999;115(5):1265-70. https://doi.org/10.1378/ chest.115.5.1265

20. Fornari F, Gruber AC, Lopes Ade B, Cecchetti D, de Barros SG. Symptom's questionnaire for gastroesophageal reflux disease [Article in Portuguese]. Arq Gastroenterol. 2004;41(4):263-7. https://
doi.org/10.1590/S0004-28032004000400012

21. Cunha JA. Manual da versão em português das Escalas Beck. São Paulo: Casa do Psicólogo; 2001

22. Global Initiative for Asthma (GINA). Global strategy for asthma management and prevention. Bethesda: GINA; 2015

23. Pereira CA, Duarte AA, Gimenez A, Soares MR. Comparison between reference values for FVC, FEV1, and FEV1/FVC ratio in White adults in Brazil and those suggested by the Global Lung Function Initiative 2012. J Bras Pneumol. 2014;40(4):397-402. https://doi.org/10.1590/ S1806-37132014000400007

24. de Groot JC, Storm H, Amelink M, de Nijs SB, Eichhorn E, Reitsma $\mathrm{BH}$, et al. Clinical profile of patients with adult-onset eosinophilic asthma. ERJ Open Res. 2016;2(2). pii: 00100-2015. https://doi. org/10.1183/23120541.00100-2015

25. Zhang $X Y$, Simpson JL, Powell H, Yang IA, Upham JW, Reynolds $\mathrm{PN}$, et al. Full blood count parameters for the detection of asthma inflammatory Phenotypes. Clin Exp Allergy. 2014;44(9):1137-45. https://doi.org/10.1111/cea.12345

26. Obesity: preventing and managing the global epidemic. Report of a WHO consultation. World Health Organ Tech Rep Ser. 2000;894:i-xii, $1-253$

27. The IDF consensus worldwide definition of the metabolic syndrome Brussels: International Diabetes Federation; 2005.

28. Lintomen L, Calixto MC, Schenka A, Antunes E. Allergen-induced bone marrow eosinophilopoiesis and airways eosinophilic inflammation in leptin-deficient ob/ob mice. Obesity (Silver Spring). 2012;20(10):1959-65. https://doi.org/10.1038/oby.2012.93

29. Ma J, Xiao L. Association of general and central obesity and atopic and nonatopic asthma in US adults. J Asthma. 2013;50(4):395-402. https://doi.org/10.3109/02770903.2013.770014

30. Chen Y, Rennie D, Cormier Y, Dosman J. Atopy, obesity, and asthma in adults: the Humboldt study. J Agromedicine. 2009;14(2):222-7. https://doi.org/10.1080/10599240902724051

31. Fenger RV, Gonzalez-Quintela A, Vidal C, Gude F, Husemoen $\mathrm{LL}$, Aadahl $\mathrm{M}$, et al. Exploring the obesity-asthma link: do all types of adiposity increase the risk of asthma? Clin Exp Allergy. 2012;42(8):1237-45. https://doi.org/10.1111/j.13652222.2012.03972x

32. Flegal KM, Kruszon-Moran D, Carroll MD, Fryar CD, Ogden CL. Trends in obesity among adults in the United States, 2005 to 2014. JAMA. 2016;315(21):2284-91. https://doi.org/10.1001/jama.2016.6458

33. Anderson WJ, Lipworth BJ. Does body mass index influence responsiveness to inhaled corticosteroids in persistent asthma? Ann Allergy Asthma Immunol. 2012;108(4):237-42. https://doi. org/10.1016/j.anai.2011.12.006

34. Mosen DM, Schatz M, Magid DJ, Camargo CA Jr. The relationship between obesity and asthma severity and control in adults. J Allergy Clin Immunol. 2008;122(3):507-11.e6. https://doi.org/10.1016/j. jaci.2008.06.024

35. Sin DD, Jones RL, Man SF. Obesity is a risk factor for dyspnea but not for airflow obstruction. Arch Intern Med. 2002;162(13):1477-81. https://doi.org/10.1001/archinte.162.13.1477

36. Farah CS, Kermode JA, Downie SR, Brown NJ, Hardaker KM, Berend $\mathrm{N}$, et al. Obesity is a determinant of asthma control, independent of inflammation and lung mechanics. Chest. 2011;140(3):659-666. https://doi.org/10.1378/chest.11-0027

37. Brumpton $B$, Langhammer A, Romundstad $P$, Chen $Y$, Mai XM General and abdominal obesity and incident asthma in adults: the HUNT study. Eur Respir J. 2013;41(2):323-9. https://doi. org/10.1183/09031936.00012112

38. Guh DP, Zhang W, Bansback N, Amarsi Z, Birmingham CL, Anis AH The incidence of co-morbidities related to obesity and overweight: a systematic review and meta-analysis. BMC Public Health. 2009;9:88. https://doi.org/10.1186/1471-2458-9-88 